\title{
Performance Analysis of Flat and Rippled Wick-Inverted V-Type Solar Still Integrated with Drip System in Kerala Climatic Conditions
}

\author{
T. Namshad, ${ }^{1}$ K. R. Ayush, ${ }^{1}$ K. C. Salih, ${ }^{1}$ Athul James, ${ }^{1}$ Suficker Ahammed, ${ }^{1}$ \\ Hashim Vayalilakath, ${ }^{1}$ and P. U. Suneesh ${ }^{2}$ \\ ${ }^{1}$ M E S College of Engineering, Kuttippuram, Kerala 679 573, India \\ ${ }^{2}$ R\&D Centre, Bharathiyar University, Coimbatore 641 046, India
}

Correspondence should be addressed to K. R. Ayush; nahasnes@gmail.com

Received 10 June 2013; Accepted 6 August 2013

Academic Editors: C. Koroneos and Q. Qiao

Copyright (C) 2013 T. Namshad et al. This is an open access article distributed under the Creative Commons Attribution License, which permits unrestricted use, distribution, and reproduction in any medium, provided the original work is properly cited.

Thermal aspect of solar energy is widely used in the desalination plants. Experimental investigation and mathematical modeling of inverted V-type solar still integrated with drip system are presented in this paper. The experiment is performed in the Kerala climatic conditions $\left(10.8439^{\circ} \mathrm{N}, 76.0328^{\circ} \mathrm{E}\right)$, March 2012 at M E S College of Engineering, Kuttippuram. A two segment still of $2 \mathrm{~m}^{2}$ is constructed. Experimental investigations on productivity and internal heat transfer are analyzed. The results indicate that the mean standard deviations between theoretical and experimental values are less than 7\% (temperature of rippled wick), 8\% (temperature of glass in rippled system), $11 \%$ (temperature of flat wick), and 7\% (temperature of glass in flat system), an average for the working hours of the day.

\section{Introduction}

Wick-type solar stills are widely accepted and are known for high distillate yield. Velmurugan et al. [1] have studied that wick-type stills show improved distillate yield compared to the conventional water filled stills. Minasian and Alkaraghouli [2] have experimentally investigated an improved design of the single slope coupled to a wick in order to enhance still output. The energy absorbed by the absorber basin is mostly transferred to the water. As a result, water gets heated. In water filled system, early hour radiations are used for acquiring latent heat of evaporation to a greater extent, and then evaporated water gets condensed on the inner surface of the top cover by releasing its latent heat. So, most of the water filled systems show high distillate yield after noon. Phadatare and Verma [3] have studied the variation of productivity with respect to water depth and have concluded that productivity decreases with an increase of water depth. Kalidasa Murugavel and Srithar [4] have conducted experiments on basin-type solar still with different wick materials and concluded optimized output using light cotton wick. The effects of climatic, design, and operational parameters on the productivity of the wick-type solar still have been mentioned by Yeh and Chen [5]. Talbert et al. [6] and Tanaka et al. [7] have mentioned that the wick-type solar still has attractive performance against the basin-type solar still. In this work, a new rippled wick-type solar still integrated with drip system has been constructed; a comparative study has been conducted with flat wick-type solar still. A transient theory has been proposed to validate the ripple effect.

\section{Materials and Methods}

A sectional and photographic view of solar still is presented in Figures 1(a), 1(b), and 2. As seen in Figure 1, water in the tank feeds into the still using a drip system, and the rate of flow is controlled by an external valve. The basin is made of mild steel. Length and breadth of the still are given as $2.00 \mathrm{~m}$ and $1.00 \mathrm{~m}$, respectively. Bottom and sides of the still 


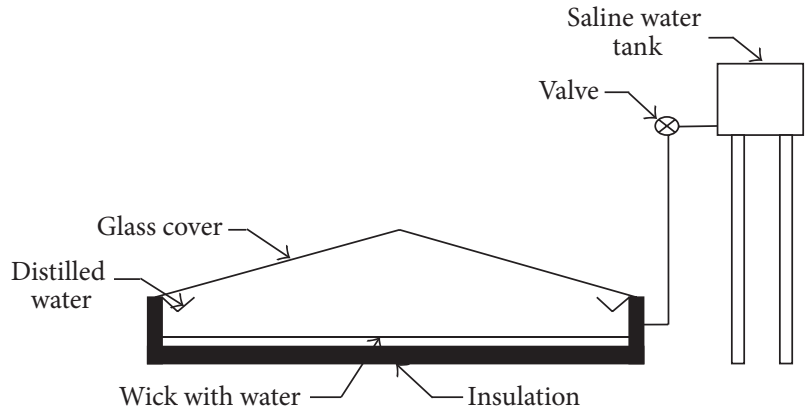

(a)

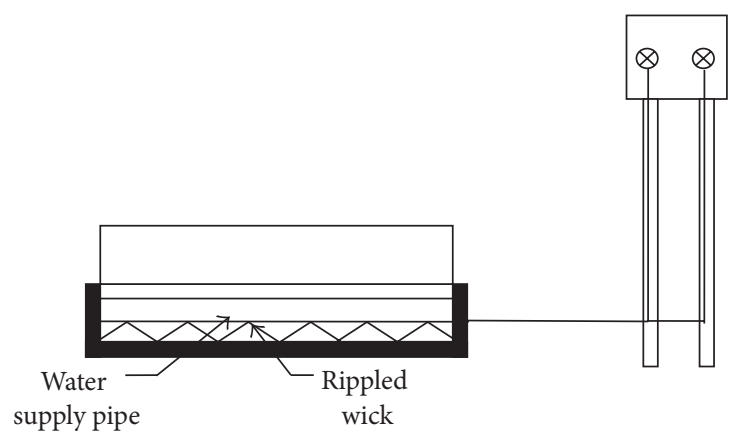

(b)

Figure 1: (a) Cross-sectional view of the still (front view). (b) Cross-sectional view of still (side view).

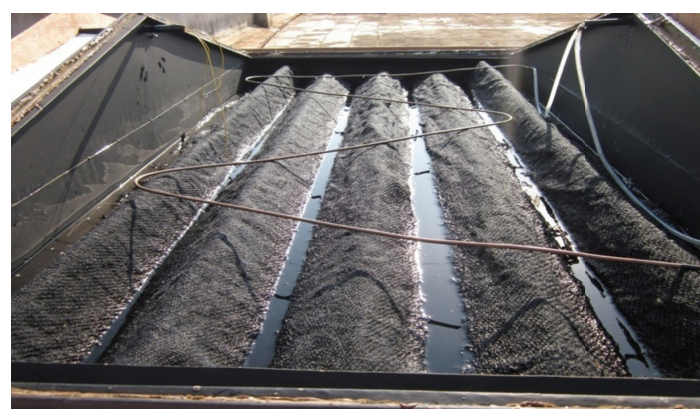

FIgURE 2: Photographic view of still.

were painted black for good absorption of solar radiation. An inlet pipe of $1 / 2$ inch has been used on either side for pouring water into the still. Heat loss is reduced by providing a wooden case with insulation. Entire still area is covered by black jute wick. It is made sure that the entire wick has been made wet using drip system. Experiments were carried out in the month of March, 2012. The experimental study conducted from 9:00 to 17:00 hours. The still was operated in the shadow-free place. Cu-Constantan thermocouples were used to measure the temperature. The air temperature inside the still $\left(T_{a}\right)$, wick temperature $\left(T_{w}\right)$, glass cover temperature $\left(T_{g}\right)$, and solar radiation were recorded at the regular intervals of time. The potable water collection at the outlet position was also recorded at regular intervals.

\section{Mathematical Model}

The following assumptions are made in the mathematical modeling of the system. Heat loss is negligible across the side wall and basin liner of the system. Variation of incident angle of solar radiation is negligible. The glass plates and basin are assumed to be parallel. Water, wick, and basin plates are considered as a single element, and ambient temperature is taken as a constant. The energy balance of the glass cover and wick surface is necessary to model the system.

3.1. Energy Balance for Glass Cover. The energy received by the glass cover includes incident solar radiation and energy received from wick surface. The energy balance equation for the glass cover is given by

Energy received by the glass cover $=$ Energy lost from the glass cover

$$
\begin{gathered}
\alpha_{g}^{\prime} I(t)+\frac{h_{1}\left(T_{w}-T_{g}\right)}{\cos (\theta)}=h_{2}\left(T_{g}-T_{a}\right) . \\
h_{1}=h_{c w}+h_{e w}+h_{r w} .
\end{gathered}
$$

The convective heat transfer coefficient from the wick surface $h_{c w}$ is given by Dunkle's relation [8]:

$$
h_{c w}=0.884\left[\left(T_{w}-T_{g}\right)+\frac{\left(P_{w}-P_{g}\right)\left(T_{w}+273.15\right)}{268900-P_{w}}\right]^{1 / 3} .
$$

The partial pressure of water vapour in the air in $\mathrm{N} / \mathrm{m}^{2}$, is estimated for a given temperature $\left({ }^{\circ} \mathrm{C}\right)$ using the following correlation [9]:

$$
P=7235-431.43 T+10.76 T^{2} .
$$

The evaporative heat transfer coefficient $h_{e w}$ is given by

$$
h_{e w}=16.276 * 10^{-3} * h_{c w} * \frac{P_{w}-P_{g}}{T_{w}-T_{g}} .
$$

The radiation heat transfer coefficient $h_{r w}$ is given by [10]

$$
h_{r w}=\frac{\sigma\left(T_{w}^{2}+T_{g}^{2}\right)\left(T_{w}+T_{g}\right)}{\left(1 / \varepsilon_{w}\right)+\left(1 / \varepsilon_{g}\right)-1} .
$$

Heat transfer from glass to air is due to convection and radiation:

$$
h_{2}=h_{c g}+h_{r g}
$$

The convective heat transfer coefficient from the glass cover is given by [11]

$$
h_{c g}=2.8+3.0 \mathrm{~V}
$$


The radiative heat transfer from the glass to air is given by

$$
h_{r g}=\varepsilon_{\mathrm{eff}} \sigma\left(\left(T_{g}\right)^{2}+\left(T_{s}\right)^{2}\right)\left(T_{g}+T_{s}\right) .
$$

The sky temperature $T_{s}$ is given by [12]

$$
T_{s}=0.0552 T_{a}^{1.5} .
$$

3.2. Energy Balance for Wick Surface. Solar energy received by the wick surface is used for raising the temperature of wick surface together with water. Energy is lost from the wick to glass cover by convection, evaporation, and radiation. Energy balance for the wick surface is given by

Energy received by wick surface $=$ Energy loss from wick surface

$$
\begin{aligned}
\alpha_{w}^{\prime} I(t)= & \left(m_{w} c_{w}+m_{\mathrm{wm}} c_{\mathrm{wm}}+m_{\mathrm{bm}} c_{\mathrm{bm}}\right) \\
& \times \frac{d T_{w}}{d t} * \frac{1}{\cos (\theta)}+h_{1}\left(T_{w}-T_{g}\right) * \frac{1}{\cos (\theta)} .
\end{aligned}
$$

Using energy balance equations of wick and glass, modified differential equation in $T_{w}$ can be written as

$$
\frac{d T_{w}}{d t}+C_{3} T_{w}=C_{4}
$$

where,

$$
\begin{gathered}
C_{3}=\frac{h_{1}\left(1-C_{2}\right)}{m_{w} c_{w}+m_{\mathrm{wm}} c_{\mathrm{wm}}+m_{\mathrm{bm}} c_{\mathrm{bm}}}, \\
C_{4}=\frac{\alpha_{w}^{\prime} I(t) \cos ^{\prime}(\theta)+h_{1} C_{1}}{m_{w} c_{w}+m_{\mathrm{wm}} c_{\mathrm{wm}}+m_{\mathrm{bm}} c_{\mathrm{bm}}}, \\
C_{1}=\frac{\alpha_{g}^{\prime} I(t)+h_{2} T_{a}}{h_{2}+1 / \cos (\theta)}, \\
C_{2}=\frac{h_{1} / \cos (\theta)}{h_{2}+h_{1} / \cos (\theta)} .
\end{gathered}
$$

\section{Result and Discussion}

Initial temperature of water, wick, and glass was assumed to be equal to ambient temperature, and average wind speed was found to be $1 \mathrm{~m} / \mathrm{s}$. In theoretical modeling, ambient temperature is taken as $30^{\circ} \mathrm{C}$. Experiments were conducted with angle of ripple $\theta=0^{\circ}$ and $\theta=45^{\circ}$. Valve system is controlled so that the wick absorber is just wet, and thus it prevents excess of water inside the still. Drip system makes sure that water distribution is uniform over the wick.

The hourly variation of solar intensity corresponding to March 10, 2012 at M E S College of Engineering, Kuttippuram $\left(10.8439^{\circ} \mathrm{N}, 76.0328^{\circ} \mathrm{E}\right)$ is presented in Figure 3, which have been used for computation. Radiation received was in the range of $100 \mathrm{~W} / \mathrm{m}^{2}$ to $910 \mathrm{~W} / \mathrm{m}^{2}$. In Figure 4 , numerical calculation and experimental observations of water temperatures are shown. In both cases, the temperature increases first and reaches a maximum in the range of $12: 00 \mathrm{pm}$ to

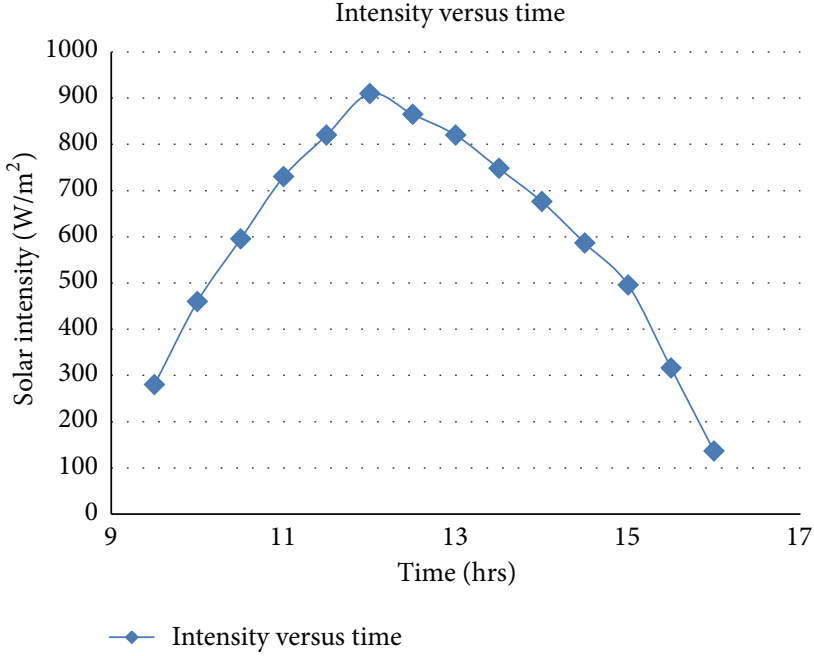

Figure 3: Solar radiation.

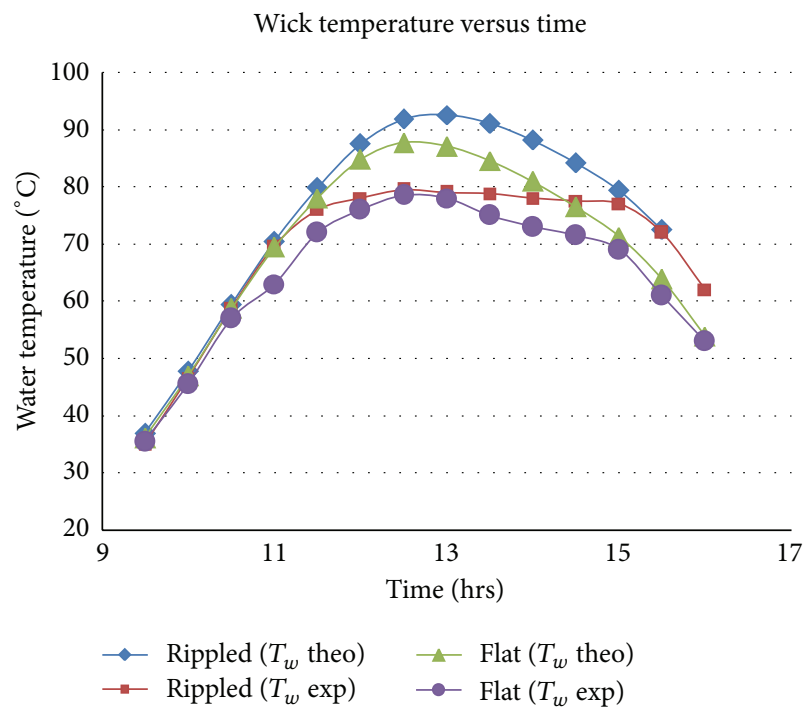

FIgURE 4: Variation of water temperatures with time.

2:00 pm and then decreases. It is clear that experimental and theoretical results have the same trend.

Figure 5 shows the theoretical and experimental variations of glass temperature. Comparing Figures 4 and 5, it is clear that the water temperature is higher for flat system. The solar radiation received is uniformly distributed over the absorber. The area of flat plate is less than that of rippled plate. So, the solar energy absorbed per unit area is higher, and hence the temperature is larger. This effect is reflected in the yield rate of the system. Experimental value of average wick temperature in rippled system is found to be $66.52^{\circ}$ whereas theoretical value for the same system is $71.63^{\circ}$ (mean deviation $7 \%$ ). Similarly, mean deviations in the temperature profile of other parameters are very small. Average mean deviation in the temperature profile of the system by the proposed modeling is less than $9 \%$. 


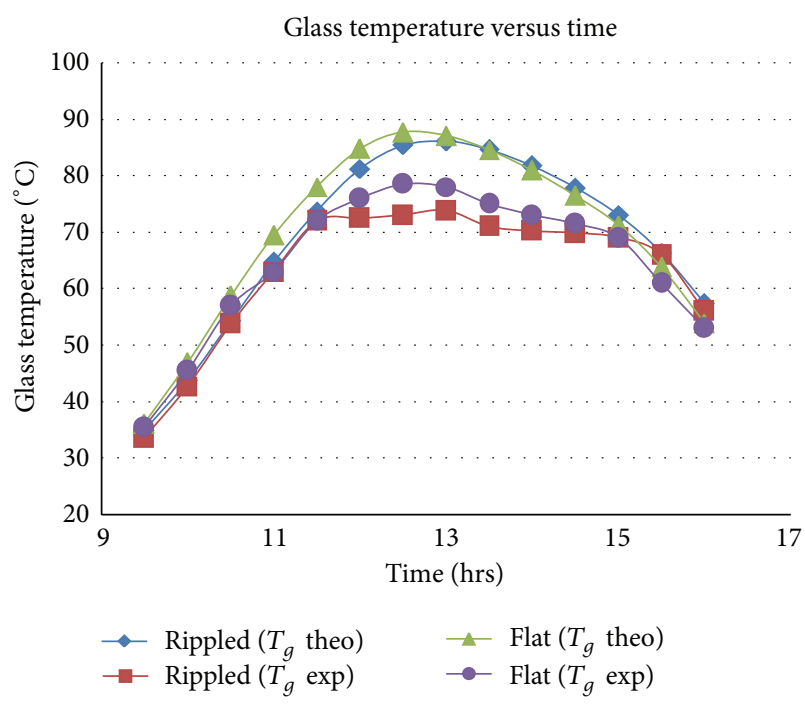

FIGURE 5: Variation of glass temperatures with time.

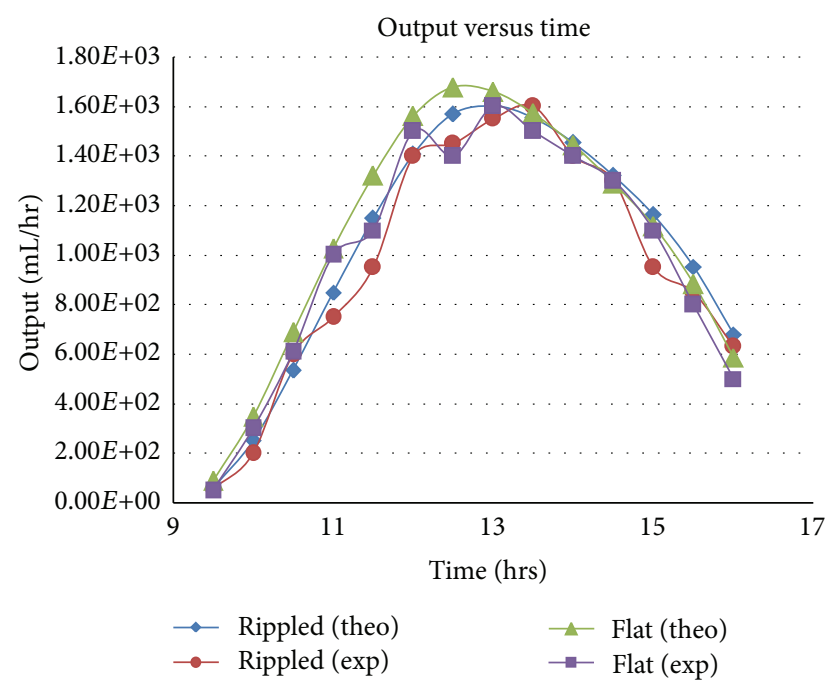

FIGURE 6: Variation of output with time.

Variation of still output with time is shown in Figure 6 corresponding to a base volume of $25 \mathrm{~L}$. From the figure, it is clear that still with flat absorber has large output compared to still with rippled absorber. As the angle of ripple increases, even though the area of evaporation is increased, there will be a reduction in the amount of water vapour evaporated. For both the cases, the output was found to be maximum at peak radiation times.

\section{Conclusion}

Solar still with flat and rippled absorber plate was fabricated and tested. The output from flat system and rippled system was found to be around $7.5 \mathrm{~kg} /$ day and $7.11 \mathrm{~kg} /$ day, respectively. The mathematical modeling and experimental study of the system lead to the following conclusion. (i) The wick temperature for the flat plate is higher than that of the rippled plate.

(ii) The still output is higher for the flat system.

(iii) The still output decreases as the angle of ripple increases.

Total solar radiation received will be independent of the angle of ripple. Increasing the area of ripple will reduce the amount of water evaporated.

\section{Nomenclature}

C: Specific heat $(\mathrm{J} / \mathrm{kgK})$

$h$ : Heat transfer coefficient $\left(\mathrm{W} / \mathrm{m}^{2} \mathrm{~K}\right)$

I: Intensity of solar radiation $\left(\mathrm{W} / \mathrm{m}^{2}\right)$

m: Mass flow rate $(\mathrm{kg} / \mathrm{s})$

$P$ : Pressure $\left(\mathrm{N} / \mathrm{m}^{2}\right)$

$T$ : Temperature $(\mathrm{K})$

$t:$ Time (s)

$V:$ Velocity of wind $(\mathrm{m} / \mathrm{s})$

$\alpha^{\prime}$ : Fraction of solar radiation absorbed

$\theta$ : Angle of the ripple

$\varepsilon:$ Emissivity.

\section{Subscripts}

$\begin{array}{ll}g: & \text { Glass } \\ w: & \text { Water } \\ a: & \text { Ambient } \\ c w: & \text { Convective from water } \\ e w: & \text { Evaporative from water } \\ r w: & \text { Radiative from water } \\ c g: & \text { Convective from glass } \\ r g: & \text { Radiative from glass } \\ \text { eff: } & \text { Effective } \\ S: & \text { Sky } \\ \text { wm: Wick material } \\ \text { bm: Base material. }\end{array}$

\section{References}

[1] V. Velmurugan, M. Gopalakrishnan, R. Raghu, and K. Srithar, "Single basin solar still with fin for enhancing productivity", Energy Conversion and Management, vol. 49, no. 10, pp. 26022608, 2008.

[2] A. N. Minasian and A. A. Al-Karaghouli, "An improved solar still: the wick-basin type," Energy Conversion and Management, vol. 36, no. 3, pp. 213-217, 1995.

[3] M. K. Phadatare and S. K. Verma, "Influence of water depth on internal heat and mass transfer in a plastic solar still," Desalination, vol. 217, no. 1-3, pp. 267-275, 2007.

[4] K. Kalidasa Murugavel and K. Srithar, "Performance study on basin type double slope solar still with different wick materials and minimum mass of water," Renewable Energy, vol. 36, no. 2, pp. 612-620, 2011.

[5] H. M. Yeh and L. C. Chen, "The effects of climatic, design and operational parameters on the performance of wick-type solar distillers," Energy Conversion and Management, vol. 26, no. 2, pp. 175-180, 1986. 
[6] S. Talbert, J. Eibling, and G. Lof, "Manual on solae distillation of saline water," OSW, R\&D Report 546, US Department of the Interior, Washington, DC, USA, 1970.

[7] K. Tanaka, A. Yamashita, and K. Watanabe, Solar World Forum, vol. 2, Pergamon Press, Oxford, UK, 1982.

[8] R. V. Dunkle, "Solar water distillation, the roof type still and a multiple effect diffusion still, International Developments in Heat Transfer," in Proceedings of the ASME International Heat Transfer, Part 5, p. 895, University of Colorado, 1961.

[9] S. Toure and P. Meukam, "A numerical model and experimental investigation for a solar still in climatic conditions in Abidjan (Côte d'Ivoire)," Renewable Energy, vol. 11, no. 3, pp. 319-330, 1997.

[10] J. Duffie and W. Beckman, Solar Engineering of Thermal Processes, John Wiley and Sons, New York, NY, USA, 2nd edition, 1991.

[11] J. H. Watmuff, W. W. S. Charters, and D. Proctor, "Solar and wind induced external coefficients solar collectors," Revue Internationale Heliotechnique, vol. 2, p. 56, 1977.

[12] V. B. Sharma and S. C. Mullick, "Estimation of heat-transfer coefficients, the upward heat flow, and evaporation in a solar still," Journal of Solar Energy Engineering, vol. 113, no. 1, pp. 3641, 1991. 


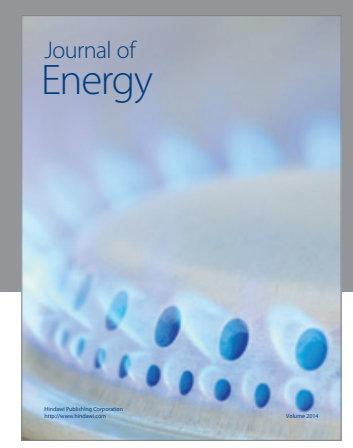

Journal of

Industrial Engineering
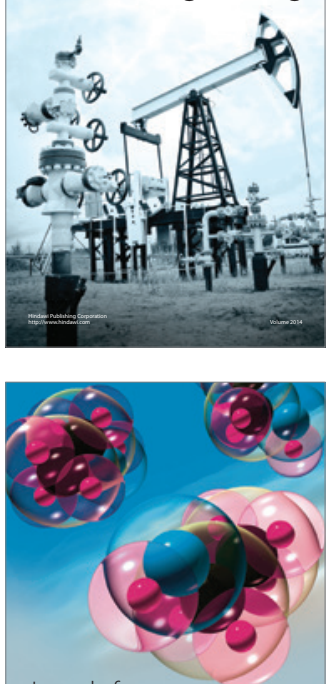

Fuels
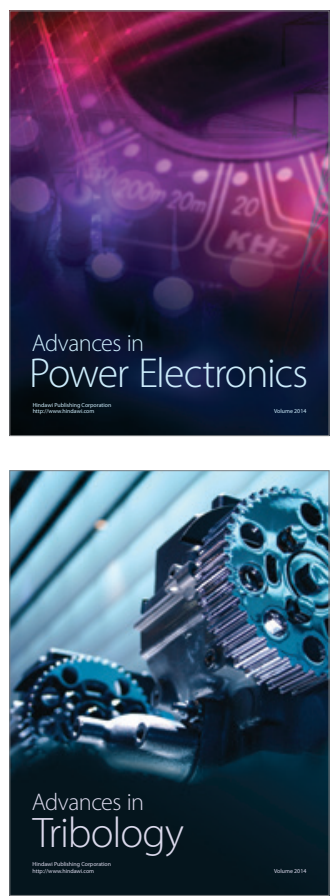

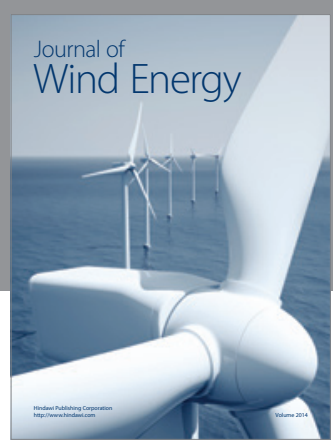

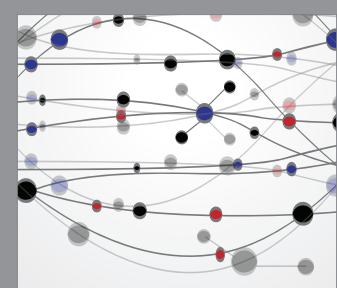

The Scientific World Journal

Submit your manuscripts at http://www.hindawi.com

Journal of

Structures
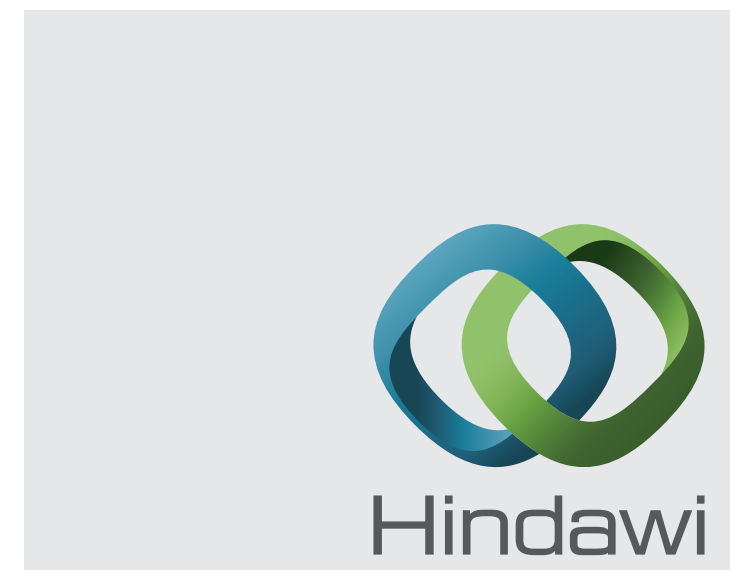

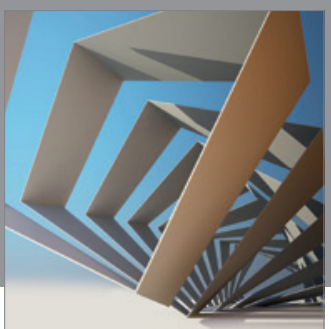

Rotating

Machinery
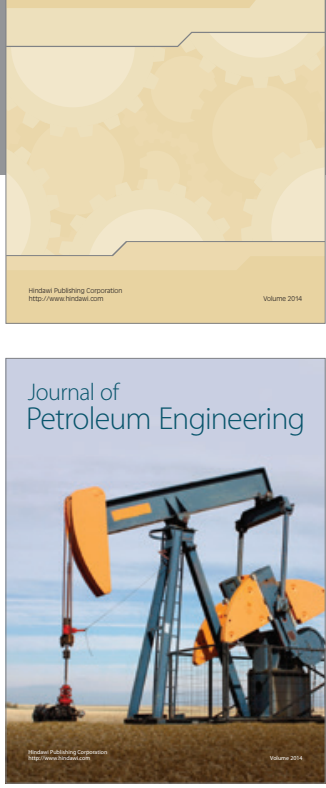

Journal of

Solar Energy
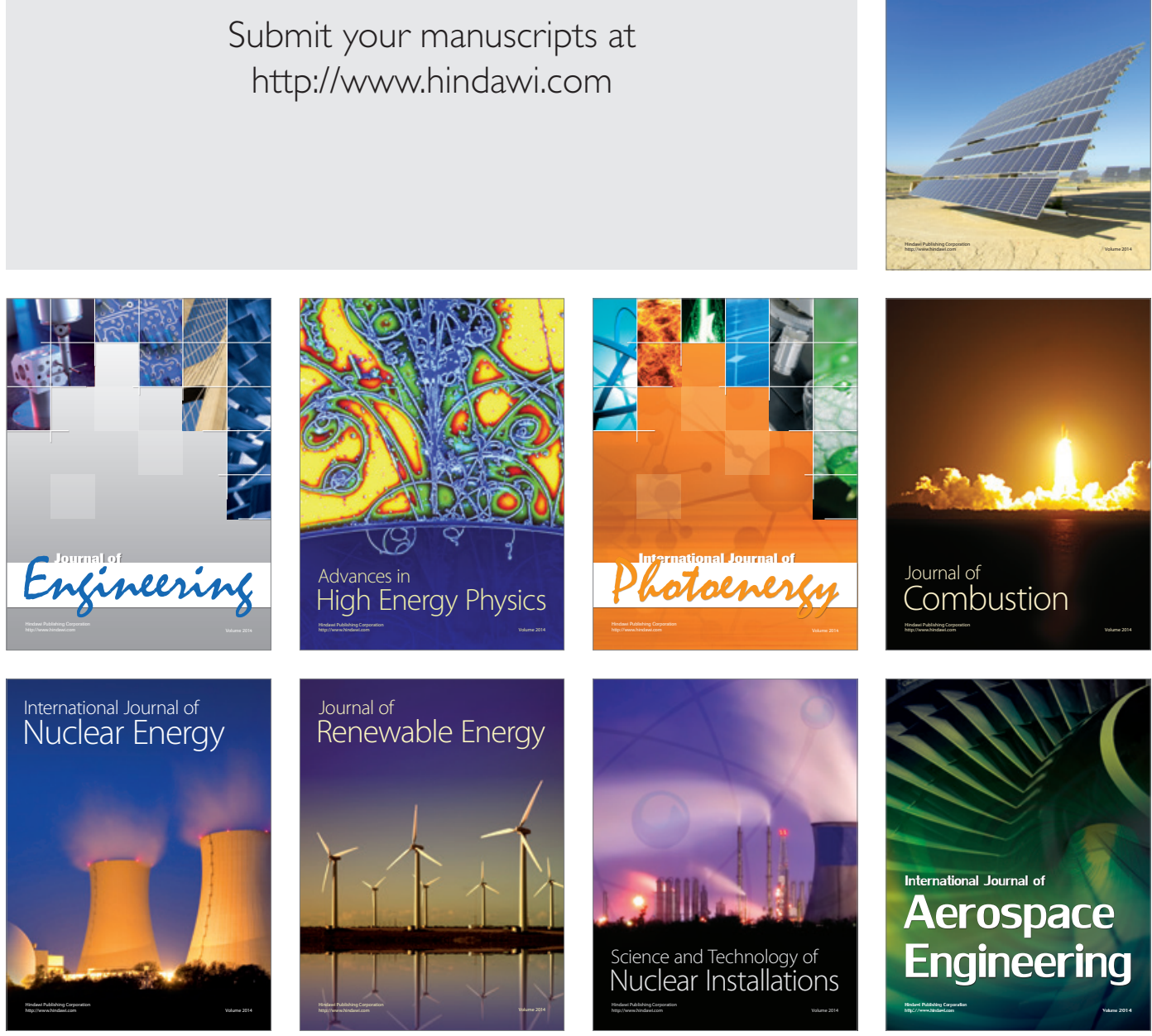